\title{
Effect of Minimal Processing and Packaging on Physico Chemical Composition of Carrots (Daucus carota)
}

\author{
Sahil Sharma, Julie Dogra Bandral", Monika Sood, Neeraj Gupta and Adil Afzal Mir
}

Division of Food Science and Technology, Sher-e-Kashmir University of Agricultural Sciences and Technology of Jammu, Main Campus, Chatha, Jammu-180009, India

*Corresponding author

\begin{tabular}{|l|}
\hline K e y w o r d s \\
Carrot, Minimal \\
processing, Carboxy \\
methyl cellulose, Sucrose, \\
Sensory scores
\end{tabular}

\section{Introduction}

The fresh cut fruits and vegetables industry is constantly growing mainly due to the consumer's tendency of health consciousness and their increasing interest in the role of food for maintaining and improving human wellbeing (Omus-Oliu et al., 2010). Minimally processed products have been defined as any fruit or vegetables or any combination thereof, which has been physically altered from its original but has remained in its fresh condition (IFPA, 2000).

Minimally processed vegetables (fresh cut vegetables) are highly perishable because of exposed internal tissue, lack of skin, a cuticle for protection and activated metabolism. The main changes in the products are increased metabolic activity, enzymatic browning and 
presence of micro organisms and pathogens in the plant tissues that have been processed.

In the fresh produce industry especially with fruits and vegetables, edible coatings have been used in an attempt to preserve fresh cut products because the coatings act as barriers to water loss and gas exchange, creating a micro modified atmosphere around products. Edible films are thin films prepared from edible material that act as a barrier to external elements (factors such as moisture, oils, gases and vapors) and thus protect the product, extend its shelf life and improve its quality (Krochta and Mulder-Johnston, 1997). The need is basically emphasized based on the increasing demand for high quality minimal processed food and storage technologies.

Minimal processed carrots (Daucus carota L.) are ready to eat products with a limited shelf life due to physiological disorder called "white blush". Formation of whitish appearance on the surface of the peeled carrots has been attributed to dehydration and possible formation of lignin in response to peeling (Baldwin et al., 1995). Therefore, some dipping treatments and edible coatings or acidic environment can be used to inactivate the lignification process which is enzyme mediated. Also, losses of carotene have been reported in fresh cut carrots and with application of edible coatings, about 50 per cent retention can be obtained. Therefore, in this study suitability of edible coatings along with chlorine dip combined with packaging was investigated to prevent the quality loss during storage of fresh cut minimally processed carrot.

\section{Materials and Methods}

\section{Procurement of raw materials}

Good quality fresh carrot vegetables were purchased from the local market. Two packaging materials viz. polypropylene bags of $0.02 \mathrm{~mm}$ thickness and polystyrene trays with shrink wrap covering were used for packaging of minimally processed carrots in $250 \mathrm{gm}$ packaging. The edible coatings viz. carboxy methyl cellulose (CMC) and sucrose were used for coatings of minimally processed carrots. Prior to coating, the carrots were given chlorine dip, ascorbic acid dip and finally benzoic acid dip.

\section{Preparation of minimally processed carrots}

The whole carrots were peeled and the head and tail were removed. The prepared carrots were washed thoroughly and given chlorine dip $(0.1 \%)$ for 3 minutes followed by benzoic acid dip (1\%) for 2 minutes and drained properly. After dip, the minimally processed carrots (MPC) were sliced into slices $(1 \mathrm{~cm}$ thick) and given ascorbic acid (1\%) dip for 3 minutes then subjected to below mentioned treatments and The edible coated carrots were packed in polypropylene bags and polystyrene trays covered with shrink wrap film in $250 \mathrm{gm}$ packing stored under refrigerated conditions.

$\mathrm{T}_{1}=$ Control

$\mathrm{T}_{2}=$ Minimally processed carrots $+1 \%$ carboxy methyl cellulose.

$\mathrm{T}_{3}=$ Minimally processed carrots $+2 \%$ carboxy methyl cellulose.

$\mathrm{T}_{4}=$ Minimally processed carrots $+3 \%$ carboxy methyl cellulose.

$\mathrm{T}_{5}=$ Minimally processed carrots $+1 \%$ sucrose solution

$\mathrm{T}_{6}=$ Minimally processed carrots $+2 \%$ sucrose solution

$\mathrm{T}_{7}=$ Minimally processed carrots $+3 \%$ sucrose solution 


\section{Physico-chemical analysis}

\section{Colour values ( $L^{*}, a^{*}$ and $\left.b^{*}\right)$}

Color analysis of the minimally processed carrots was done by using Hunter Lab colorimeter using method of Vargas et al., (2009).

\section{Rotting index}

Rotting index was calculated based on number of carrot discs showing symptoms of decay (D) to the total no of carrot discs per bag (TC) at the end of 21 days of storage (Ngure et al., 2009).

$\operatorname{ID}(\%)=\left[(\mathrm{D} / \mathrm{TC})^{*} 100\right]$

Total soluble solids, titratable acidity and reducing sugars

Total soluble solids (TSS), Titratable acidity and Reducing Sugars were measured by using standard procedure as given by (Ranganna, 2006).

\section{pH}

The $\mathrm{pH}$ was determined by using $\mathrm{pH}$ meter calibrated with a standard buffer solution of $\mathrm{pH}$ as described by AOAC (2002).

\section{Total plate count}

Total plate count of micro-organisms present in toffees was estimated as per Palczar and Chan (1991). Firstly 1: 10 dilution was prepared by mixing the $1 \mathrm{~g}$ in $9 \mathrm{~mL}$ buffered peptone water and homogenize for $1 \mathrm{~min}$, followed by serial dilution. An amount of 15 $\mathrm{mL}$ cooled media was poured aseptically into pre-sterilized Petri-dishes. The plates were incubated in inverted positions for $24 \mathrm{~h}$ at $35^{\circ} \mathrm{C}$. Then colonies were counted after 24 to $36 \mathrm{~h}$.

\section{Overall acceptability scores}

Sensory evaluation depends upon the responses given by different sense organs. The samples were evaluated for overall acceptability by semi-trained panel of 7-8 judges by using 9 point hedonic scale assigning scores 9- like extremely to 1- dislike extremely. A score of 5.5 and above was considered acceptable (Amerine et al., 1965).

\section{Statistical analysis}

All the experiments were conducted in factorial completely randomized design with each treatment replicated three times The data was analyzed to test statistical significance as per Panse and Sukhatme (1967).

\section{Results and Discussion}

\section{Colour values}

There was a significant increase in $L^{*}$ values (Table 1a) of minimally processed carrot with the advancement in storage period. The treatment $\mathrm{T}_{1}$ (control) recorded the highest $\mathrm{L}^{*}$ value of 53.11 in polypropylene bags and 53.18 in shrink wrap after 7 days of storage. However, after 21 days of storage treatment, $\mathrm{T}_{7}$ (3\% sucrose) recorded the lowest value of 52.82 in polypropylene bags and 52.91 in shrink wrap.

In case of $a^{*}$ values (Table $1 b$ ), the highest value of 43.47 in polypropylene bags and 43.59 in shrink wrap were recorded in $\mathrm{T}_{4}(3 \%$ $\mathrm{CMC}$ ) and the lowest values of 38.68 in polypropylene bags and 38.81 in shrink wrap were recorded in $\mathrm{T}_{1}$ (control). As the storage period advanced, a decrease in a ${ }^{*}$ values was observed. A significant decrease in $b^{*}$ values (Table 1c) was noticed during storage and the mean values decreased from 26.70 to 25.40 in polypropylene bags and 26.70 to 25.58 in shrink wrap packaged minimally processed 
carrots. Karande et al., (2014) also reported increase in $\mathrm{L}^{*}$ of minimally processed carrots during low temperature storage in PP and LDPE bags. Spokowski (2010) and Djioua et al., (2009) also reported similar findings during refrigerated storage of broccoli, cauliflower and carrots and minimally processed mangoes. Increase in $\mathrm{L}^{*}$ values and decrease in $a^{*}$ and $b^{*}$ values in minimally processed pumpkin coated with xanthan gum, chitosan and glycerol have been reported by Cortez-Vega (2014) and Incedayi et al., (2009) and this was due to reduced impairment of the visual aspect of pumpkin cubes after use of edible coatings.

\section{Rotting index}

Rotting index (Table 2) showed an increasing trend during storage period. $\mathrm{T}_{1}$ (control) recorded the maximum rotting index of 4.80 per cent in polypropylene bags and 4.58 per cent in shrink wrap after 14 days of refrigerated storage, however, the minimum rotting index content of 1.55 per cent in polypropylene bags and 1.40 per cent in shrink wrap were noticed in $\mathrm{T}_{5}(1 \%$ sucrose $)$.

After 21 days of storage, highest rotting index content of 9.39 per cent in polypropylene bags and 9.11 per cent in shrink wrap were recorded by $\mathrm{T}_{1}$ (control) where as a minimum of 3.76 per cent in polypropylene bags and 3.64 per cent in shrink wrap were observed in treatment $\mathrm{T}_{3}$ (2\% CMC). Ngure et al., (2009) reported that storage and packaging affected quality of okra pods because packaging might have improved moisture retention and reduced exposure to micro-organisms and contaminants. Mastromatteo (2012) demonstrated that coating fresh cut carrots with sodium alginate followed by packaging into perforated polypropylene film prevents dehydration and microbial proliferation, delays respiratory activity and enhances quality of product stored at $4^{0} \mathrm{C}$.

\section{Total soluble solids}

Storage period and packaging also significantly influenced the TSS content (Table 3) of minimally processed carrots. The treatment $\mathrm{T}_{7}(3 \% \mathrm{CMC})$ recorded the highest TSS content of $11.80{ }^{\circ}$ Brix in polypropylene bags and $11.93{ }^{\circ}$ Brix in shrink wrap at 7 days of storage. However, after 21 days of storage treatment $\mathrm{T}_{1}$ (control) recorded the lowest value of $11.80{ }^{\circ}$ Brix in polypropylene bags and $12.02{ }^{\circ}$ Brix in shrink wrap packed minimal processed carrots Opoku et al., (2009) also reported increase in TSS content of refrigerated stored carrots.

Rashidi and Bahri et al., (2009) also reported increase in TSS content during storage of carrots. Increase of TSS is caused through starch hydrolysis by $\alpha$ - amylase enzyme during storage (Wills et al., 2007). Manoj et al., (2016) and Marpudi (2011) also gave similar findings in edible coated bell pepper and papaya during storage.

\section{Titratable acidity}

The titratable acidity (Table 4) increased during refrigerated storage of minimally processed carrots and after 7 days of storage period, the highest titratable acidity of 0.23 per cent in polypropylene bags and 0.22 per cent in shrink wrap were recorded by treatment $\mathrm{T}_{5}\left(1 \%\right.$ sucrose), whereas, $\mathrm{T}_{4}(3 \%$ $\mathrm{CMC}$ ) recorded the lowest titratable acidity of 0.17 per cent in polypropylene bags and 0.16 per cent in shrink wrap packaged minimally processed carrots. The mean titratable acidity increased from 0.18 to 0.23 per cent in polypropylene bags and from 0.18 to 0.22 per cent in shrink wrap packed carrots during 21 days storage. Geeta (2015) and Cortez-Vega et al., (2014) also reported increase in acidity of minimally processed carrots and pumpkin cubes during storage. This was due to increase in organic acids. 
Table.1 (a) Effect of edible coatings and packaging on $\mathrm{L}^{*}$ values in minimally processed carrots during refrigerated storage

\begin{tabular}{|c|c|c|c|c|c|c|c|c|c|c|}
\hline \multirow{4}{*}{ Treatments } & \multicolumn{10}{|c|}{ Packaging } \\
\hline & \multirow{2}{*}{\multicolumn{5}{|c|}{ Polypropylene }} & \multicolumn{5}{|c|}{ Shrink wrap } \\
\hline & & & & & Storage (days) & \multicolumn{5}{|c|}{ Storage (days) } \\
\hline & $\mathbf{0}$ & 7 & 14 & 21 & Mean & $\mathbf{0}$ & 7 & 14 & 21 & Mean \\
\hline $\mathrm{T}_{1}$ (Control) & 52.84 & 53.11 & 53.58 & 53.87 & 53.35 & 52.84 & 53.18 & 53.67 & 54.0 & 53.42 \\
\hline $\mathrm{T}_{2}(1 \% \mathrm{CMC})$ & 52.48 & 52.70 & 52.99 & 53.32 & 52.87 & 52.48 & 52.86 & 53.19 & 53.72 & 53.06 \\
\hline $\mathrm{T}_{3}(2 \% \mathrm{CMC})$ & 51.80 & 52.23 & 52.43 & 53.07 & 52.38 & 51.80 & 52.40 & 52.89 & 53.34 & 52.61 \\
\hline $\mathrm{T}_{4}(3 \% \mathrm{CMC})$ & 51.53 & 51.90 & 52.36 & 52.96 & 52.19 & 51.53 & 52.16 & 52.71 & 53.10 & 52.38 \\
\hline $\mathrm{T}_{5}(1 \%$ Sucrose $)$ & 52.32 & 52.58 & 52.84 & 53.24 & 52.75 & 52.32 & 52.72 & 52.98 & 53.65 & 52.92 \\
\hline $\mathrm{T}_{6}(2 \%$ Sucrose $)$ & 51.75 & 52.18 & 52.31 & 53.00 & 52.31 & 51.75 & 52.36 & 52.90 & 53.23 & 52.56 \\
\hline $\mathbf{T}_{7}$ (3\% Sucrose) & 51.30 & 51.76 & 52.13 & 52.82 & 52.00 & 51.30 & 51.82 & 52.43 & 52.91 & 52.12 \\
\hline Mean & 52.00 & 52.35 & 52.66 & 53.18 & & 52.00 & 52.50 & 52.97 & 53.42 & \\
\hline \multicolumn{11}{|l|}{$\begin{aligned} \mathrm{CD}_{(\mathrm{P}=0.05)} & \\
& \text { Packaging (A) } \\
& \text { Storage (B) } \\
& \text { Treatments (c) }\end{aligned}$} \\
\hline
\end{tabular}

Table.1 (b) Effect of edible coatings and packaging on a values in minimally processed carrots during refrigerated storage

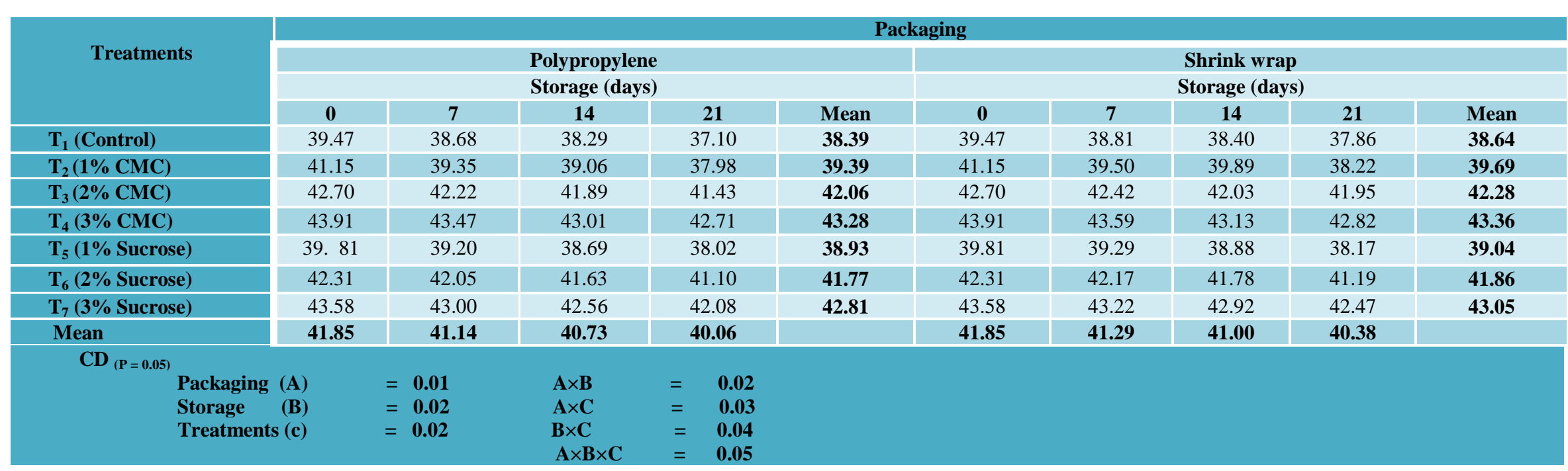


Table.1 (c) Effect of edible coatings and packaging on $b^{*}$ values in minimally processed carrots during refrigerated storage

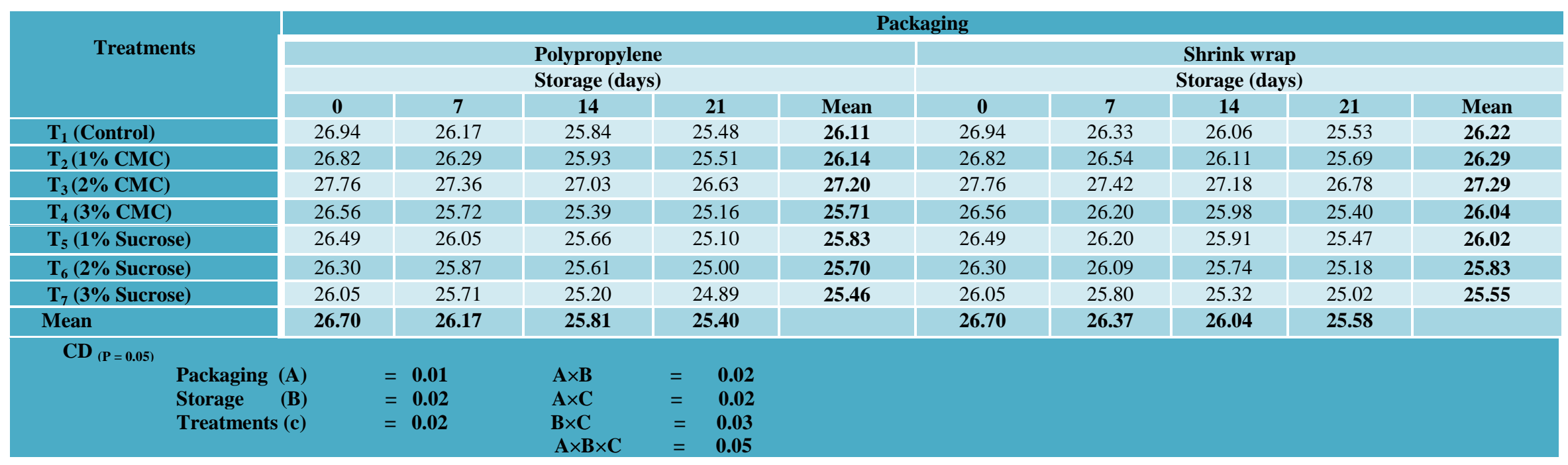

Table.2 Effect of edible coatings and packaging on rotting index (\%) in minimally processed carrots during refrigerated storage

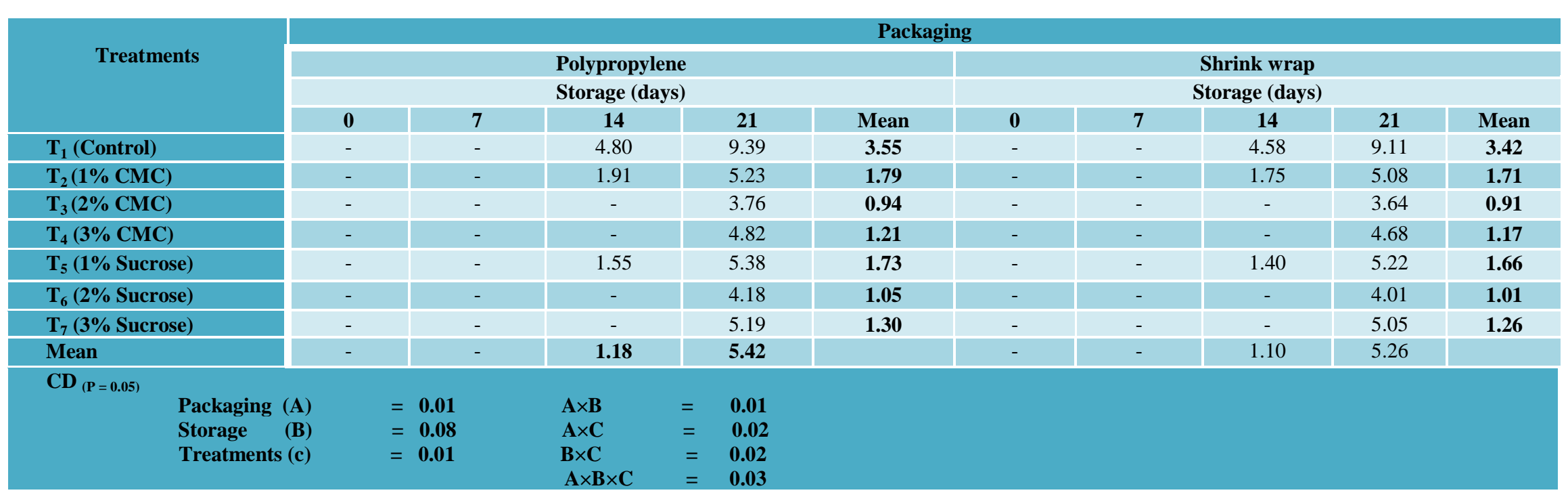


Table.3 Effect of edible coatings and packaging on TSS $\left({ }^{0} \mathrm{~B}\right)$ in minimally processed carrots during refrigerated storage

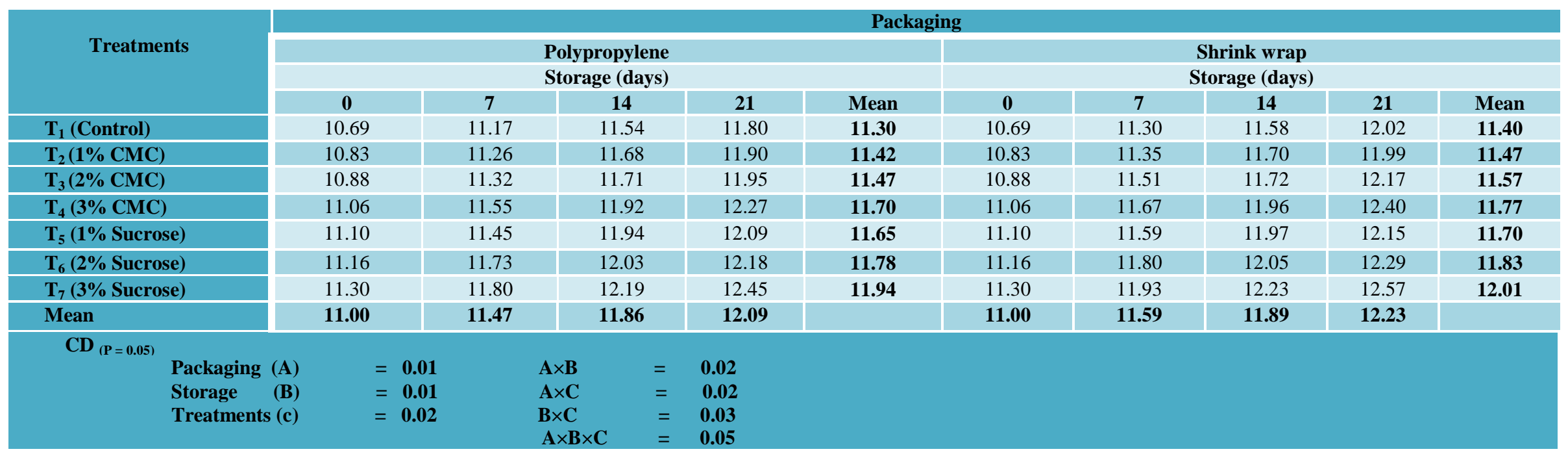

Table.4 Effect of edible coatings and packaging on titrable acidity (\%) in minimally processed carrots during refrigerated storage

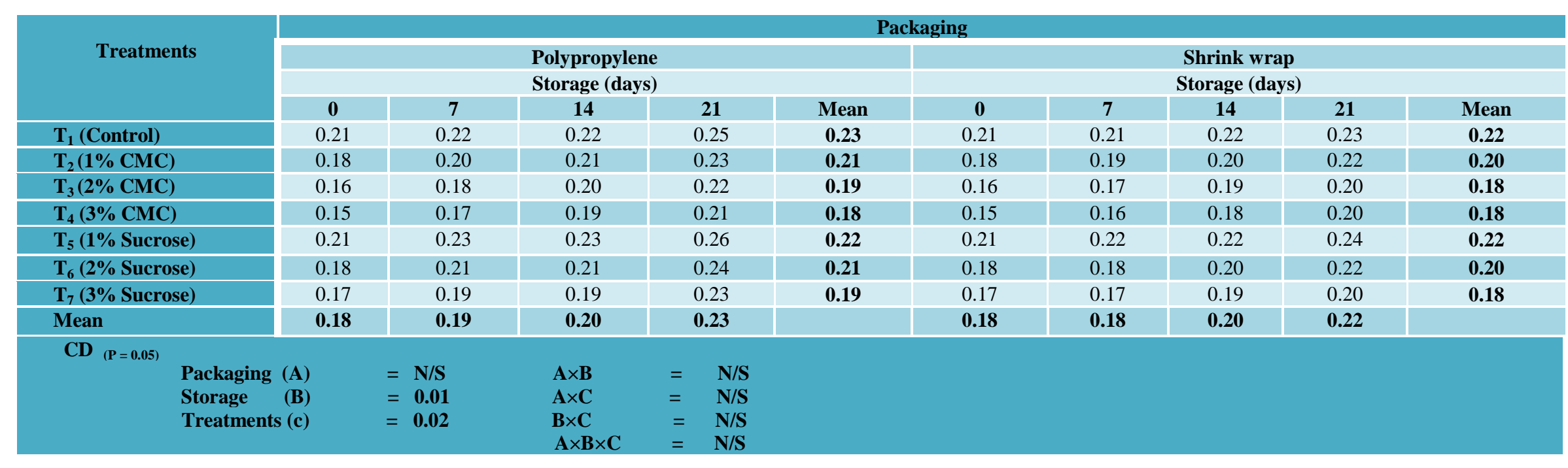


Table.5 Effect of edible coatings and packaging on $\mathrm{pH}$ in minimally processed carrots during refrigerated storage

\begin{tabular}{|c|c|c|c|c|c|c|c|c|c|c|c|c|}
\hline \multirow{4}{*}{\multicolumn{2}{|c|}{ Treatments }} & \multicolumn{11}{|c|}{ Packaging } \\
\hline & & \multicolumn{6}{|c|}{ Polypropylene } & \multicolumn{5}{|c|}{ Shrink wrap } \\
\hline & & \multicolumn{6}{|c|}{ Storage (days) } & \multicolumn{5}{|c|}{ Storage (days) } \\
\hline & & 0 & 7 & 14 & 21 & & Mean & $\mathbf{0}$ & 7 & 14 & 21 & Mean \\
\hline $\mathrm{T}_{1}$ (Control) & & 6.13 & 6.17 & 6.22 & 6.27 & & 6.19 & 6.13 & 6.16 & 6.20 & 6.24 & 6.18 \\
\hline $\mathrm{T}_{2}(1 \% \mathrm{CMC})$ & & 6.16 & 6.20 & 6.26 & 6.30 & & 6.23 & 6.16 & 6.19 & 6.24 & 6.29 & 6.22 \\
\hline $\mathrm{T}_{3}(2 \% \mathrm{CMC})$ & & 6.14 & 6.18 & 6.24 & 6.29 & & 6.21 & 6.14 & 6.17 & 6.22 & 6.27 & 6.20 \\
\hline $\mathrm{T}_{4}(3 \% \mathrm{CMC})$ & & 6.20 & 6.26 & 6.32 & 6.39 & & 6.29 & 6.20 & 6.24 & 6.29 & 6.34 & 6.27 \\
\hline $\mathrm{T}_{5}(1 \%$ Sucrose $)$ & & 6.25 & 6.30 & 6.35 & 6.40 & & 6.33 & 6.25 & 6.28 & 6.32 & 6.37 & 6.31 \\
\hline $\mathrm{T}_{6}(2 \%$ Sucrose $)$ & & 6.23 & 6.29 & 6.37 & 6.41 & & 6.32 & 6.23 & 6.27 & 6.32 & 6.35 & 6.29 \\
\hline $\mathrm{T}_{7}$ (3\% Sucrose) & & 6.28 & 6.32 & 6.39 & 6.43 & & 6.35 & 6.28 & 6.30 & 6.35 & 6.39 & 6.33 \\
\hline Mean & & 6.20 & 6.25 & 6.31 & 6.35 & & & 6.20 & 6.23 & 6.28 & 6.32 & \\
\hline \multicolumn{13}{|c|}{$\begin{array}{l}\text { Packaging (A) } \\
\text { Storage (B) } \\
\text { Treatments (c) }\end{array}$} \\
\hline
\end{tabular}

Table.6 Effect of edible coatings and packaging on Total Plate Count $\left(\times 10^{4} \mathrm{cfu} / \mathrm{g}\right)$ in minimally processed carrots during refrigerated storage

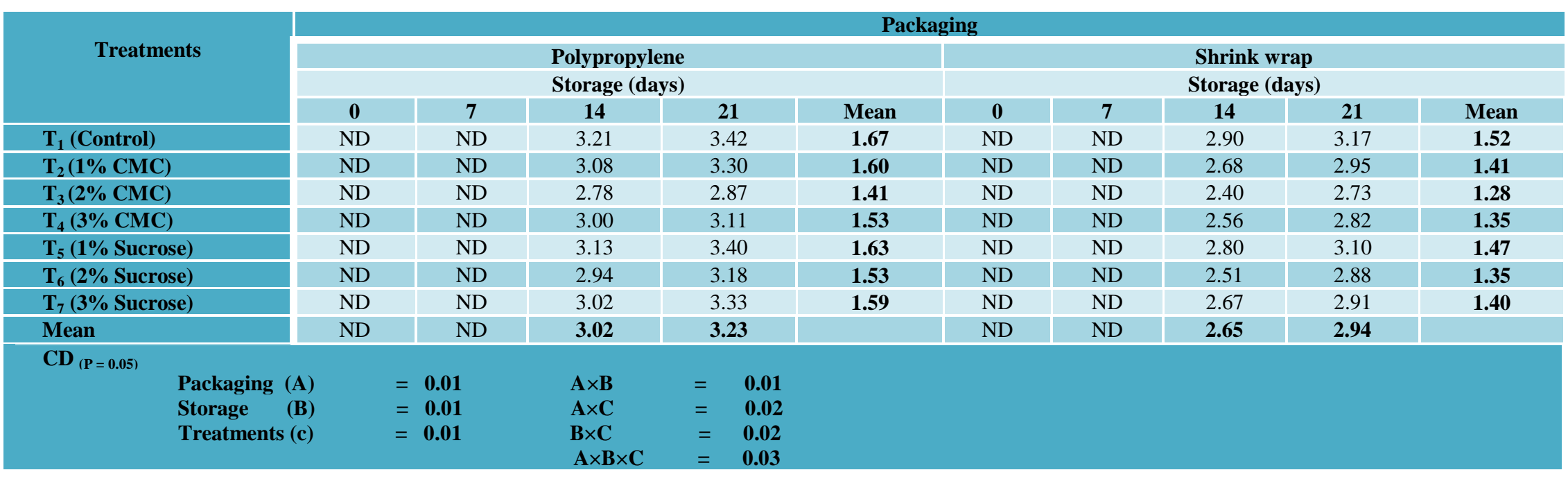


Table.7 Effect of edible coatings and packaging on overall acceptability in minimally processed carrots during refrigerated storage

\begin{tabular}{|c|c|c|c|c|c|c|c|c|c|c|}
\hline \multirow{4}{*}{ Treatments } & \multicolumn{10}{|c|}{ Packaging } \\
\hline & \multicolumn{5}{|c|}{ Polypropylene } & \multicolumn{5}{|c|}{ Shrink wrap } \\
\hline & \multicolumn{5}{|c|}{ Storage (days) } & \multicolumn{5}{|c|}{ Storage (days) } \\
\hline & $\mathbf{0}$ & 7 & 14 & 21 & Mean & 0 & 7 & 14 & 21 & Mean \\
\hline $\mathrm{T}_{1}$ (Control) & 7.97 & 6.99 & 6.52 & 5.59 & 6.77 & 7.97 & 7.05 & 6.58 & 5.70 & 6.83 \\
\hline $\mathrm{T}_{2}(1 \% \mathrm{CMC})$ & 7.91 & 7.71 & 7.53 & 7.04 & 7.55 & 7.91 & 7.77 & 7.50 & 7.13 & 7.58 \\
\hline $\mathrm{T}_{3}(2 \% \mathrm{CMC})$ & 8.06 & 7.85 & 7.70 & 7.35 & 7.74 & 8.06 & 7.94 & 7.65 & 7.42 & 7.77 \\
\hline $\mathrm{T}_{4}(3 \% \mathrm{CMC})$ & 7.93 & 7.71 & 7.63 & 7.12 & 7.60 & 7.93 & 7.79 & 7.52 & 7.18 & 7.61 \\
\hline $\mathrm{T}_{5}(1 \%$ Sucrose $)$ & 7.80 & 7.56 & 7.34 & 6.81 & 7.38 & 7.80 & 7.62 & 7.31 & 6.89 & 7.41 \\
\hline $\mathrm{T}_{6}(2 \%$ Sucrose $)$ & 7.93 & 7.70 & 7.47 & 7.14 & 7.56 & 7.93 & 7.78 & 7.45 & 7.26 & 7.61 \\
\hline $\mathrm{T}_{7}$ (3\% Sucrose) & 7.84 & 7.55 & 7.37 & 6.86 & 7.41 & 7.84 & 7.67 & 7.36 & 7.01 & 7.47 \\
\hline Mean & 7.92 & 7.58 & 7.37 & 6.84 & & 7.92 & 7.66 & 7.34 & 6.94 & \\
\hline \multicolumn{11}{|l|}{$C D_{(P=0.05)}$} \\
\hline \multicolumn{3}{|c|}{ Packaging (A) } & $=0.01$ & \multicolumn{2}{|c|}{$A \times B$} & 0.02 & & & & \\
\hline \multicolumn{3}{|c|}{ Storage } & $=0.02$ & \multicolumn{2}{|c|}{$\mathbf{A} \times \mathbf{C}$} & $\mathbf{N} / \mathbf{S}$ & & & & \\
\hline \multicolumn{3}{|c|}{ Treatments (c) } & $=0.02$ & \multicolumn{2}{|c|}{$\mathbf{B} \times \mathbf{C}$} & 0.05 & & & & \\
\hline & & & & \multicolumn{2}{|c|}{$\mathbf{A} \times \mathbf{B} \times \mathbf{C}$} & $\mathbf{N} / \mathbf{S}$ & & & & \\
\hline
\end{tabular}


Dong et al., (2004) and Hayat et al., (2005) were more of the opinion that titratable acidity was higher in control samples because coatings and packaging created microenvironment coupled with less oxidative reactions and lesser decline in degradation of acids thus maintaining the integrity of the cells.

\section{pH}

Storage period significantly influenced the $\mathrm{pH}$ value (Table 5) of minimally processed carrot during refrigerated storage. There was a significant increase in $\mathrm{pH}$ value of minimally processed carrot with the advancement in storage period. The treatment $\mathrm{T}_{4}(3 \% \mathrm{CMC})$ recorded highest $\mathrm{pH}$ value of 6.32 in polypropylene bags and 6.30 in shrink wrap after 7 days of storage.

However, after 21 days of storage treatment $\mathrm{T}_{1}$ (control) recorded the lowest value of 6.27 in polypropylene bags and 6.24 in shrink wrap. Anjum et al., (2006) and Pilon et al., 2006 also reported increase in $\mathrm{pH}$ of minimally processed carrot and CMC coated mangoes during refrigerated storage and related it to lower organic acid values found. Menezes and Athmaselvi (2016) also reported significant increase in $\mathrm{pH}$ of coated sapota during storage at $4^{\circ} \mathrm{C}$.

\section{Total plate count}

A significant increase in total plate count (Table 6) was noticed during refrigerated storage of minimally processed carrots and the mean count increased from 3.02 to 3.23 $\mathrm{x} 10^{4} \mathrm{CFU} / \mathrm{g}$ in polypropylene bags and 2.65 to $2.94 \times 10^{4} \mathrm{CFU} / \mathrm{g}$ in shrink wrap. After 14 days of storage the lowest mean total plate count of $1.41 \times 10^{4} \mathrm{CFU} / \mathrm{g}$ in polypropylene bags and $1.28 \times 10^{4} \mathrm{CFU} / \mathrm{g}$ in shrink wrap were recorded by treatment $\mathrm{T}_{3}(2 \% \mathrm{CMC})$. Microbial growth on minimally processed carrots is favoured by high moisture and numerous cut surfaces. Pilon et al., (2006) reported that refrigeration temperature below $7^{0} \mathrm{C}$ extends the shelf life of minimally processed carrot by slowing down the growth rate of microorganisms Conte et al., (2009) also reported prolonged shelf life and delayed microbial growth of minimally processed Lampascioni Muscari Comosum with Sodium alginate coating. Also, Benzoic acid dip based coating reduced microorganisms proliferation in minimally processed carrot. Similar findings of aloevera coating in papaya (Marpudi et al., 2011) and aloevera gel coating in sweet cherries (Abirami 2009).

\section{Overall acceptability}

A general decrease in overall acceptability scores (Table 7) was observed with the advancement of storage period. After 7 days of storage, the maximum scores were recorded in $\mathrm{T}_{3}(2 \% \mathrm{CMC})$, whereas the minimum scores were observed in $\mathrm{T}_{1}$ (control) in both packaging. After 21 days of storage, the highest scores of 7.35 in polypropylene bags and 7.42 in shrink wrap for overall acceptability of minimally processed carrots were recorded in $\mathrm{T}_{3}$ (2\% carboxy methyl cellulose). Porta et al., (2013) reported that carrots coated with sodium alginate followed by packaging into a micro perforated polypropylene film were acceptable for about two weeks. The results are in agreement with the findings of Mahendran (2015) and Aythan et al., (2008) for refrigerated storage of carrots. On the basis of the evaluation of range of quality parameters, it is concluded that minimally processed carrots after giving chlorine $(0.1 \%)$ and benzoic acid dip (1\%) followed by ascorbic acid dip (1\%) and finally application of edible coating with 2 per cent carboxy methyl cellulose retained fresh like characteristics up to 21 days of storage under refrigerated condition in shrink wrap packaging. 


\section{References}

Abirami, L. S. S. 2009. Efficacy of chitosan and natural plant extracts on the growth of selected fungal pathogens and control of anthracnose disease of papaya. M.Sc thesis, Sri Sathya Sai University, Prashanthi Nilayam, India.

Anjum, N., Masud, T. and Latif, A. 2006. Effect of various coating materials on keeping stored at low temperature. American Journal of Food Technology, 1: $52-58$

AOAC. 2002. Official Methods of Analysis, $\left(17^{\text {th }}\right.$ Edn $)$, Association of Official analytical Chemists, Washington D. C., New York, USA.

Aythan, Z., Esturk, O. and Tas, E. 2008. Modified atmosphere packaging on the quality and shelf life of minimally processed carrot. Turkey Journal Agriculture and Forestry, 32: 57-67.

Baldwin, E.A., Nisperos-Carriedo, M. O. and Baker, R.A. 1995. Use of edible coatings to preserve quality of lightly (and slightly) processed products. $C R C$ Critical Reviews in Food Science and Nutrition, 35: 509-524.

Conte, A., Scrocco, C., Brescia, I., Del Nobile, M. A. 2009. Packaging strategies to prolong the shelf life of minimally processed lampascioni (Muscari comosum). Journal of Food Engineering, 90: 199-206.

Cortez, V. W., Piotrowicz, I. B. B., Prentice, C. and Borges, D. C. 2014. Influence of different edible coatings in minimally processed pumpkin. International Food Research Journal, 21(5): 2017-2023.

Djioua, T., Charles, F., Lopez-Lauri, F., Filgueiras, H., Coudret, A., Jr, M. F., Ducamp Collin, M. N. and Sallanon, H. 2009. Improving the storage of minimally processed mangoes (Mangifera indica L) by hot water treatments. Postharvest Biology and Technolgy, 52: 221-226.

Dong, H., Cheng, L., Tan, J. Zheng, K. and Jiang, Y. 2004. Effects of chitisan coating on quality and shelf life of peeled Litchi fruit. Journal of Food Engineering, 64: 355-358.

Geetha, P. 2015. Effect of pre -treatments and Packaging on Shelf life of Minimally Processed Carrots. Madras Journal of Agriculture, 102: 268-272.

Hayat, I., Masud, T. and Rathore, H. A. 2005. Effect of coating and wrapping materials on the shelf life of apple (Malus domestic acv. Borkh). International Journal of Food Safety, 5: 24-34.

Incedayi, B., Tamer, C. E., Yonel, S. P. and Çopur, O. U. 2009. A research on the dessert produced from modified atmosphere packaged pumpkins. International Journal Food Agriculture and Environment, 7: 149-154.

International Fresh-cut Produce Association. IFPA. 2000. Fresh cut produce: get the facts. www.freshcuts. org.

Karande, D., Sonkar, C. and Kuthe, G. 2014. Shelf life study of minimally processed carrot through modified atmospheric packaging. International Journal of Research in Engineering and Advanced Technology, 2: 2320-8791.

Krochta, J. M. and Mulder-Johnston, D. C. 1997. Edible and biodegradable polymer films: challenges and opportunities. Food Technology, 51(2): 61-74.

Mahendran, T. 2015. Quality and shelf life of minimally processed shredded carrots in modified atmosphere packaging. International Research Conference, KDU, 8: 108-113.

Manoj, H. G., Sreenivas, K. N., Shankarappa, T. H. and Krishna, H. C. 2016. Studies on chitosan and aloe vera gel coatings on biochemical parameters and 
microbial population of bell pepper under ambient condition. International Journal of Current Microbiology and Applied Sciences, 5(1): 399-405.

Marpudi, S. L., Abirami, L. S. S., Pushkala, R. and Srividya, N. 2011. Enhancement of storage life and quality maintenance of papaya fruits using aloe vera based antimicrobial coating. Indian Journal of Biotechnology, 10: 83-89.

Mastromatteo, M., Conte, A and Del Nobile, M. A. 2012. Packaging strategies to prolong the shelf life of fresh carrots (Daucus carota L.). Innovations in Food Science and Emerging Technology, 13: 215-220.

Menezes, J. and Athmaselvi, K. 2016. Study on effect of pectin based edible coating on the shelf life of sapota fruits. Food Science and Biotechnology Research Asia, 13(2): 1195-1199.

Ngure, J. W, Aguyoh, J. N. and Gaoquiong, L. 2009. Interactive effects of packaging and storage temperatures on the shelf-life of okra. ARPN Journal of Agricultural and Biological Science, 4(3): 44-49.

Omus-Oliu, G., Rojas-Grau, M. A., Gonzalez, L. A., Varela, P., Soliva-Fortuny, R., Hernando, M.I.H., Munuera, I. P., Fiszman, S. and Martin-Belloso, $\mathrm{O}$. 2010. Recent approaches using chemical treatments to preserve quality of fresh cut fruit - A review. PostHarvest Biology and Technology, 57: 139-148.

Opoku, A., Meda, V. and Wahab, J. 2009. Effects of storage methods on quality characteristics of carrots grown under organic and conventional management. Prince Edward Island, 702: 1-17.

Palczar, M. J. and Chan, E.C.S.1991. Laboratory Exercise in Microbiology. Black Dot Inc., New York.

Pilon, L., Oetterer, M., Gallo, C.R. and Spoto, M. H. F. 2006. Shelf life of minimally processed carrot and green pepper. Ciência e Tecnologia de Alimentos campina, 26(1): 150-158.

Porta, R., Marquez, G. R, Mariniello, L., Sorrentino, A., Giosafatto, C. V. L., Esposito, M. and Pierro, P. D. 2013. Edible coating as packaging strategy to extend the shelf life of fresh cut fruits and vegetables. Journal of Biotechnology and Biomater, 3: 1-3.

Ranganna, S. 2006. Manual of Analysis of Fruits and Vegetables Products. Tata McGraw Hill Publishing Company Ltd. New Delhi.

Spokowski, A. 2010. Vaccum effect of refrigerated storage on shelf life of comingled brocioli, cauliflower and carrots. M.Sc. thesis, Clemson University.

Vargas, M., Chiralt, A., Albors, A. and Gonzalez-Martinez, C. 2009. Effect of chitosan-based edible coatings applied by vaccum impregnation on quality preservation of fresh cut carrot. Postharvest Biology and Technology, 51: 263- 271.

Wills, R. B. H., W. B. McGlasson, D. G. and Joyce, D. C. 2007. Postharvest. Oxfordshire: UNSW Press.

\section{How to cite this article:}

Sahil Sharma, Julie Dogra Bandral, Monika Sood, Neeraj Gupta and Adil Afzal Mir. 2018. Effect of Minimal Processing and Packaging on Physico Chemical Composition of Carrots (Daucus carota). Int.J.Curr.Microbiol.App.Sci. 7(05): 3301-3312. doi: https://doi.org/10.20546/ijcmas.2018.705.386 